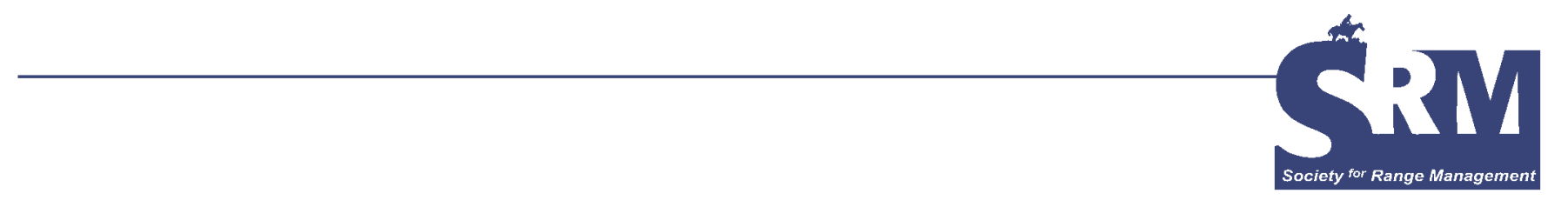

\title{
The Effect of Cattle Grazing on Native Ungulates: The Good, the Bad, and the Ugly
}

By Natalia A. Chaikina and Kathreen E. Ruckstuhl

\section{Introduction}

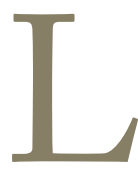

ivestock grazing pressure on native vegetation has been an important concept for many rangeland managers, as well as livestock owners, for many years. One particular question addresses the effects of cattle grazing on native ungulates, such as deer, elk, and bighorn sheep. Multiple studies had demonstrated that some level of cattle grazing could cause a decrease in forage availability for wild ungulates, such as mule deer (Ocodoileus hemionus), ${ }^{1,2}$ bighorn sheep (Ovis canadensis), ${ }^{3}$ and elk (Cervus elaphus). ${ }^{4}$ Several studies indicate a direct forage competition between cattle and native ungulates, such as elk, ${ }^{5}$ deer, ${ }^{5}$ mule deer, ${ }^{6}$ and, in the Indian TransHimalaya, wild bharal (Pseudois nayaur). ${ }^{7}$ Overgrazing can also cause a change in range structure, for example by decreasing hiding cover for mule deer. ${ }^{8}$ Intense cattle grazing has been associated with lower weights and reduced fat content and reproductive rates in female white-tailed deer (Odocoileus virginianus); it also had negative impacts on translocation success of bighorn sheep, ${ }^{10}$ and decreased white-tailed deer survival. ${ }^{11}$

Although many examples indicate negative impacts of cattle grazing on wild ungulates, the effects of grazing on range conditions are not always clear. The objective of this review is to address the following questions:

This article has been peer reviewed.

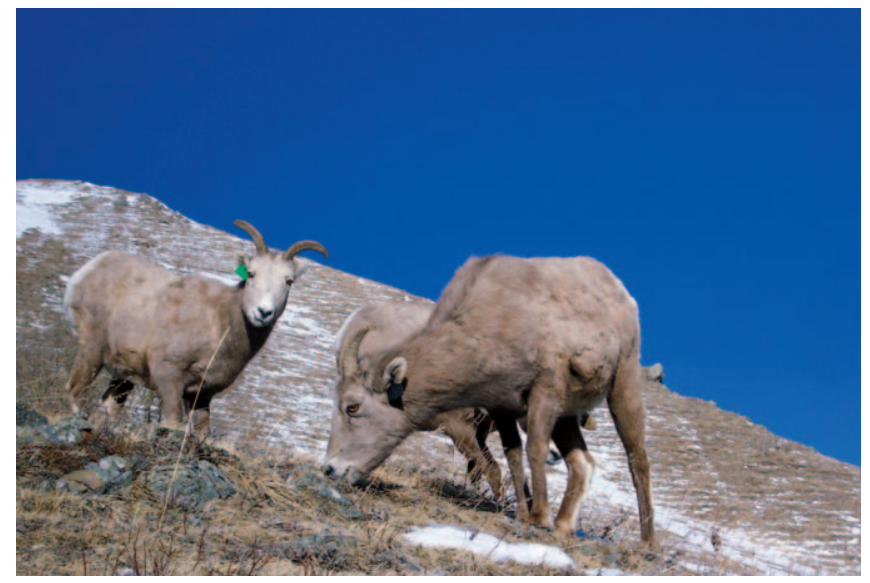

Group of female bighorn sheep grazing on the slope of a hill. Photo courtesy of Natalia Chaikina.

Has livestock grazing consistently been shown to be detrimental in the past, or are there cases where grazing had no consequences or was beneficial to native ungulates?

In cases where grazing was found to be beneficial, what timing and intensity of the application produced the best effects?

If grazing was detrimental, in which ways did it affect the big game animals and how is it possible to reduce or eliminate these damaging impacts?

Is it possible to find an acceptable balance between preservation of the environment and economic benefits of cattle production? 


\section{The Impact Sources}

\section{Diet Overlap}

One of the first questions that needs to be investigated is whether or not there is forage competition between cattle and native ungulates. Competition for resources requires these 2 groups to have dietary and spatial overlap, as well as limited resources. ${ }^{12}$ Many studies have found potential diet overlap between cattle and big game animals, but there is great variation in results depending on wild game species, areas of study, and time of the year. Campbell and Johnson ${ }^{13}$ looked at the dietary overlap between cattle, mule deer, and mountain goats (Oreamnos americanus) on Chopaka Mountain, Washington. They found that most overlap occurred between mountain goat and mule deer diets (37\%) and mountain goat and cattle diets (32\%). There was least overlap between diets of mule deer and cattle (15\%). Olsen and Hansen ${ }^{14}$ as well as Mackie $^{15}$ found a large diet overlap between cattle and elk. Hansen and Reid ${ }^{16}$ found some diet overlap, up to $48 \%$ between deer and elk, 38\% between deer and cattle, and 51\% between elk and cattle in southern Colorado. Willms et a ${ }^{17}$ reported that cattle and deer had significant range overlap in British Columbia, because both used mainly open forests and clearings. Even though diet overlap between livestock and deer was not high, it increased as forage became less available.

On the other hand, Kingery et a $1^{18}$ reported that cattle and elk in northern Idaho foraged mainly on graminoids, even though elk exhibited a broader diet range than cattle. Whitetailed deer consumed mainly forbs and shrubs. There was some potential competition between elk and cattle, but not between cattle and deer in this case. Pordomingo and Rucci ${ }^{19}$ argued that, with proper management, cattle and deer can use the same ranges with minimal competition. Deer are more adapted to browsing and selecting better quality plants and cattle have better ability to digest low-quality grasses. Stewart et $\mathrm{al}^{20}$ used stable isotopes from fecal samples of cattle, elk, and mule deer in order to show significant differences in diets of these 3 species in western North America. Hansen et $\mathrm{al}^{21}$ reported a small diet overlap between cattle and deer in the Douglas Mountain area, Colorado.

Even though cattle and wild ungulates focus on different kinds of vegetation, diet overlap increases when forage becomes less available, which usually happens in winter and early spring. For example, Thill and Martin ${ }^{22}$ showed that diet overlap between white-tailed deer and cattle on pastures in central Louisiana was greatest in the winter (30.7\%). However, the intensity of cattle grazing did not have a major impact on the diet overlap. The study suggests that late fall and winter cattle grazing can be detrimental to the availability of forage for deer. Thill ${ }^{23}$ also suggested that white-tailed deer and cattle diets on the forest sites had the greatest overlap during winter and spring seasons. Ortega et $\mathrm{al}^{24}$ looked at diet overlap between deer and cattle in Texas. Greatest overlap (60\%) was also found to occur in the winter and spring, under limited forage conditions, that resulted from shortduration heavy stocking treatment.

\section{Physical Presence of Cattle}

Grazing, as well as the physical presence of cattle, can have negative impacts on wild ungulates not only through vegetation limitation, but by causing behavioral changes and altering activity budgets that make foraging less productive. Bissonette and Steinkamp ${ }^{25}$ reported that California bighorn sheep in Big Cottonwood Canyon, Idaho, avoided cattle and decreased use of areas when cattle were in a close proximity. $\mathrm{Kie}^{26}$ found that intensity of cattle grazing pressure in California altered activity budgets of female mule deer, especially during late fall and winter when forage was limited in supply. A study of female mule deer in California's Sierra Nevada showed that deer exhibited avoidance behavior and temporal partitioning of habitat use when cattle were present. ${ }^{27}$ Stewart et $\mathrm{al}^{28}$ reported cattle avoidance behavior by elk and mule deer, who adjusted their use of the area, moving away from cattle, possibly to avoid forage competition. White-tailed deer in Louisiana altered their winter diets on sites that were continuously grazed by cattle by selecting more herbs and less browse. ${ }^{29}$ Another study done by Crimella et a ${ }^{30}$ on red deer (Cervus elaphus) showed that deer spent less time resting and feeding when cattle were present. Deer also spend more time foraging on the areas previously grazed by cattle. Wild ungulates can also exhibit a change of range use because of the presence of cattle. Loft et $\mathrm{al}^{31}$ studied female mule deer distribution in the Sierra Nevada of California in relationship to cattle grazing. The study showed that under no cattle grazing pressure deer preferred meadows and riparian habitat whereas, on moderately and heavily grazed ranges, deer used more montane shrub habitat. Yeo et $\mathrm{al}^{32}$ reported that elk and mule deer changed their habitat use as a result of rest-rotation cattle grazing in east-central Idaho.

Some studies, however, indicate little behavioral change. For example, Halstead et a ${ }^{33}$ showed that elk choice of grazing areas in central Arizona was more dependent on tree growth patterns and terrain features than on the presence or absence of cattle grazing in the area. Skovlin et $\mathrm{al}^{34}$ showed

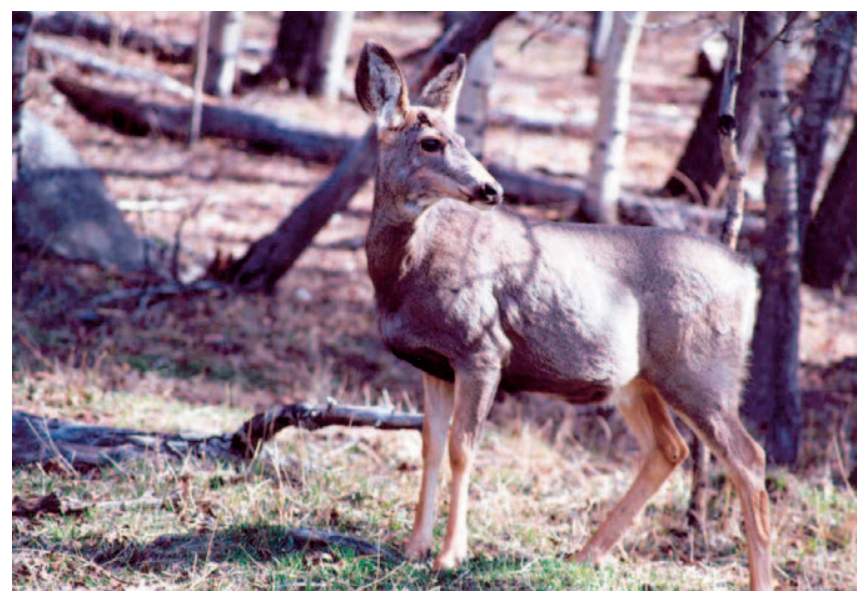

Female mule deer in the forest. Photo courtesy of Kathreen Ruckstuhl. 


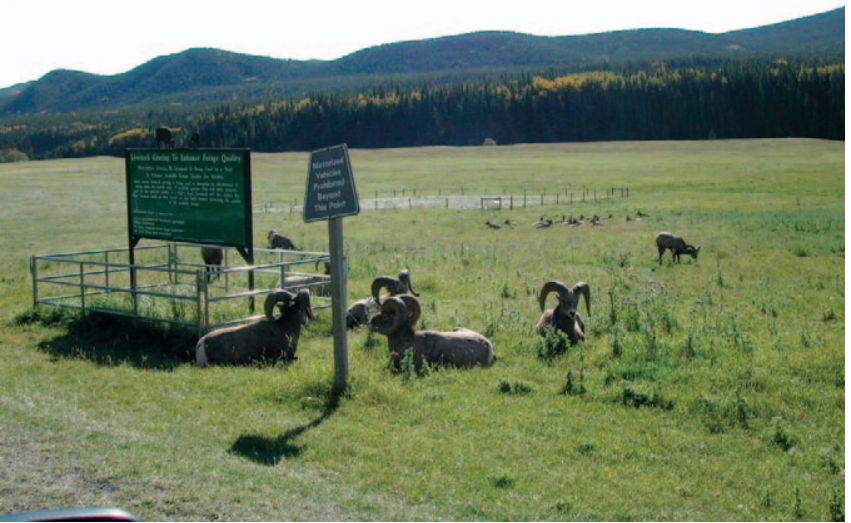

Group of male bighorn sheep lying by the cattle exclosure in the hayfields. Photo courtesy of Kathreen Ruckstuhl.

that both elk and deer range use was minimally altered under light and moderate stocking rates.

\section{Impact Indicators}

\section{Avoidance of Areas Grazed by Cattle}

Some studies have reported that wild ungulates may avoid areas used by cattle. Bowyer and Bleich ${ }^{2}$ observed fewer mule deer and less pellet groups on the grazed areas. Clegg ${ }^{35}$ showed that elk preferred ungrazed areas during rest-rotation grazing systems in Utah. Similar conclusions were drawn from the studies on elk and mule deer in Oregon, ${ }^{36,37}$ elk in Montana, ${ }^{38,39}$ and mule deer in Arizona. ${ }^{40}$

On the other hand, some studies indicate little or no avoidance effect in wild ungulates resulting from cattle presence, possibly as a result of habituation. No avoidance was detected between mule deer and cattle in central Montana. ${ }^{41}$ Austin and Urness ${ }^{42}$ observed area selection, diet composition, and dietary nutrition of mule deer. Only a slight preference for ungrazed areas was found in the beginning of the trial, which diminished with prolonged deer use of the area (over 40 days). Hart et $\mathrm{al}^{43}$ looked at elk winter ranges that were also used by cattle in the summer. Researchers used light, moderate, and heavy grazing pressure as treatments. For all treatments, little habitat overlap was actually detected, because cattle preferred to use level lowland areas, whereas elk were concentrated mostly on the high steep areas. However, it is not known whether elk were found high up because they were actively avoiding areas grazed by cattle. No control areas without cattle grazing were used in this study.

\section{Timing and Intensity of Grazing}

At times, cattle grazing can have both positive and negative results. Westenskow-Wall et $\mathrm{al}^{44}$ investigated the effects of defoliation of bluebunch wheatgrass (Agropyron spicatum) that is used as forage by elk in the Blue Mountains of northeastern Oregon. Defoliation in fall helped to increase the digestibility and phosphorus concentration of the wheat- grass, but decreased the amount of forage available. However, Wambolt et $\mathrm{al}^{45}$ found that even though grazing slightly increased nitrogen and phosphorus contents of bluebunch wheatgrass, this effect was not noticeable during the following winter.

Sometimes cattle grazing might even temporarily increase the numbers of wild ungulates, which in turn negatively affects range health. For example, heavy cattle grazing coupled with low fire frequency in early 1960s in the United States led to an increase in antelope bitterbrush, which in turn caused an increase in mule deer numbers. ${ }^{46}$ However, overgrazing in the summer caused a nutrient deficiency for mule deer in the following early spring, and large numbers of mule deer contributed to the overgrazing by deteriorating soil and vegetation. ${ }^{47}$

\section{Positive Impacts of Cattle Grazing}

An overgrazed range was defined by Wilson and Macleod ${ }^{48}$ as an area "where there is a concomitant vegetation change and loss of animal productivity arising from the grazing of land by herbivores." However, there have been some instances where controlled cattle grazing not only had no detectable negative impacts, but was shown to improve forage quality for big game animals. Vavra and Sheehy ${ }^{49}$ argued that this is possible because grazing by cattle removes last year's growth, which in turn increases the protein content of new growth. Maximum range production is achieved by removing cattle early in the summer, allowing plants to regrow. Because new growth occurs in late summer, plants grazed in early summer are unable to complete their growth cycle and transfer nutrients to the roots. Nutrients are instead trapped in the shoots, which then makes them available for ungulate grazing. However, a year of rest in between grazing treatments is required for maximum production. A similar increase in vegetation quality can be achieved by vegetation removal through clipping. ${ }^{50}$ On the other hand, this temporary increase in nutrients might be lost during the winter, which is the most critical time for ungulates. ${ }^{45}$

Scotter ${ }^{51}$ suggested that range use by both livestock and big game can help achieve and sustain the balance of browse and herbaceous forage within plant communities, thus increasing economic benefits of the land. He also suggested that livestock grazing in early spring can increase the protein content and digestibility of forage for mule deer winter diets.

Anderson and Scheninger ${ }^{52}$ argued that a specifically designed cattle-grazing system was capable of increasing the amount and quality of winter vegetation, based on elk range in northeastern Oregon. The grazing system was designed to allow sufficient time between grazing periods for plants to regrow, as well as to carefully control the grazing intensity. After the establishment of the new resource management plan, there was an increase in the quality of winter forage for elk. Elk numbers that averaged at about 120 elk for 12 years increased up to 1,190 elk and the intensity of cattle grazing was increased by 2.6 times during that period. 
Another study done on cattle and white-tailed deer in Mexico suggests that a grazed area is more stable when it is used by 2 herbivore species with different foraging patterns than by a single herbivore species. ${ }^{53}$ Cattle grazing was also reported to aid forb production and increase deer abundance, ${ }^{54}$ to improve the nutritional status of white-tailed deer, ${ }^{55}$ to improve forage conditions on deer winter range, ${ }^{56}$ and to increase deer spring preference for the pastures that were grazed by cattle in the previous fall. ${ }^{57}$

Gordon $^{58}$ also showed that winter cattle grazing in Scotland caused an increase in the amount of new vegetation in the following spring. Red deer also preferred to graze in spring on the areas that were grazed by cattle in the previous winter and had more calves per hind living on grazed areas.

There are examples that show that complete removal of cattle may even cause forage stagnation and make ranges less suitable for wild ungulates. Tueller and Tower $^{59}$ define stagnation as "the reduction in productivity of range plants resulting from a lack of grazing." Brown and Martinsen ${ }^{60}$ determined that exclusive deer and elk use of the areas for 20 or more years in eastern Washington caused both a decline in forb and browse species and a change towards the climax bunchgrass vegetation type, making the ranges more suitable for cattle grazing and less optimal for wild ungulate use. Hudson et $\mathrm{a}^{61}$ also found that grazing by white-tailed deer, mule deer, elk, and bighorn sheep alone in southeastern British Columbia caused a community shift towards more herbs and less browse, making it less suitable for browsing ungulates.

\section{Economic Issues}

The picture would not be complete without addressing the issue of the best economic gain that can be obtained from an area used by both cattle and wild ungulates. For example, Bastian et $\mathrm{a}^{162}$ used a computer model to evaluate the best economic use of the Wyoming Red Desert. They found that the benefits of the area were maximized when cattle and antelope (Antilocapra americana) were allowed to graze together. Smith et $\mathrm{al}^{63}$ also suggests that dual use of the area by mule deer and domestic sheep (Ovis aries) would increase economic yield of the ranges. Economic models of mule deer foraging on Sierra Nevada summer range indicated that under a 3-year rest-rotation grazing management, increase in the amount of rest years (from 1 to 2 years) would increase mule deer population size. This would cause increased hunting and economic benefits that would cover the losses from reduced livestock. ${ }^{64}$

\section{Impact Mitigation}

The question is, if different grazing studies give such contrary results, is it possible to determine whether or not cattle and wild ungulates can coexist as part of a healthy system? What has to be taken into account is that different levels and systems of grazing can have different effects on the forage quality and availability for native ungulates. For example,

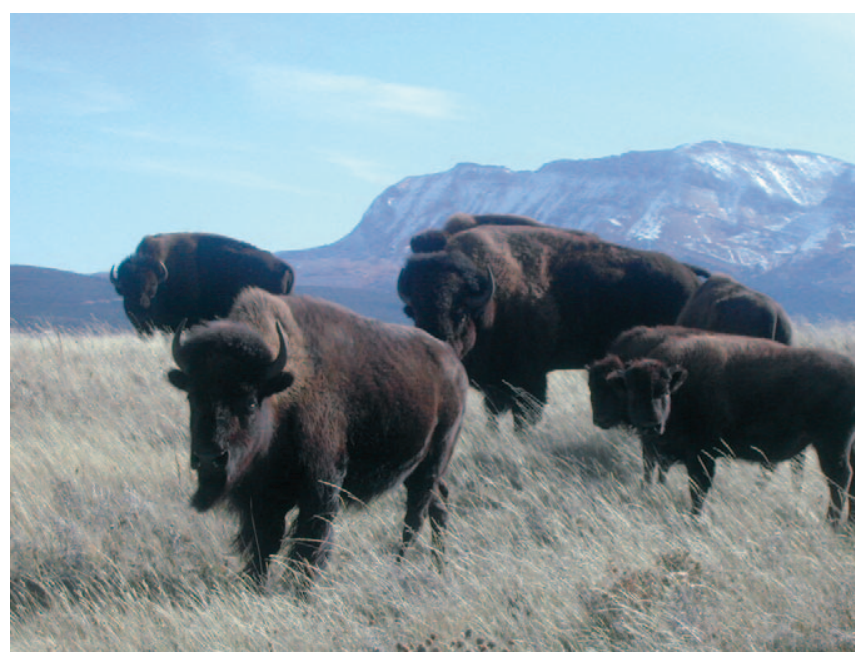

Group of bison in the prairies. Photo courtesy of Kathreen Ruckstuhl.

Cohen et $\mathrm{a}^{165}$ reported that short-duration grazing exerted more stress on white-tailed deer than did continuous grazing in southern Texas. Deer avoided cattle more and traveled more during short-duration grazing. Martinez et $\mathrm{al}^{66}$ found greater similarities between white-tailed deer and cattle diets on rotationally grazed ranges (23\%) than on continuously grazed ranges (15\%).

Another study looked at plant biomass on the ranges under short-term and continuous grazing, as well as under moderate and heavy grazing. ${ }^{24}$ Short-term grazing (when cattle are present on the range only during some part of the grazing season) is thought to be best for the range health, as it allows for the vegetation recovery. However, it was found that diet overlap between cattle and white-tailed deer increased under the short-term grazing system and that deer obtained more forbs in the continuously grazed ranges. Continuous grazing under moderate stocking rates was recommended in order to achieve better white-tailed deer management.

Timing of grazing applications is also important. Smith and Doell, ${ }^{63}$ who studied summer cattle grazing on mixedbrowse herbaceous ranges in Utah, reported that cattle grazing should be stopped by July 1 in order to avoid bitterbrush utilization by livestock and to allow enough forage for wild ungulates. Similar studies in northeastern Oregon showed that early summer cattle grazing has a minimal effect on mule deer and elk foraging efficiency. ${ }^{67}$

\section{Conclusion and Suggestions for Future Research}

In summary, this review has looked at 13 studies that showed a positive impact of cattle grazing, 31 studies that indicated a negative impact of grazing, and 23 studies that had inconclusive results. Note that the majority of the studies focused on the impact of grazing on deer, even though the diet overlap between deer and cattle is relatively small. Ungulates, such as elk, bighorn sheep, or bison, have a greater diet overlap with cattle. Future research should concentrate more on investigating the effects of cattle on ungulates that consume 
graminoids as part of their diets, because the impact of grazing should be greater for this group.

There is a great degree of inconsistency in methodology and conclusions among the results of different studies, which make comparisons difficult. One recommendation would be to come up with a systematic approach and a set of methodologies that should be used to assess the impact of cattle on ungulate range. One example of directly examining grazing competition between cattle and wild ungulates would be to exclude cattle from parts of the range. The establishment of cattle exclosures and corresponding control areas (where cattle can graze), would allow one to look at the preference of wild ungulates and to determine if grazing has an impact on big game range selection. It is possible that native ungulates might have adjusted their diets in order to compensate for cattle grazing pressure. If this was the case, then one would observe a switch-back in diet by native ungulates when cattle are excluded.

The key to establishing a sustainable grazing system, however, is to not only look at the impact of cattle grazing itself but to also assess required forage off-take by the wild ungulates. By including wild ungulates in the equation we can then account for the internal dynamics of the system. ${ }^{12}$ Uncontrolled heavy grazing by cattle will most likely cause range deterioration, decrease forage availability, and have negative effects on native herbivores. On the other hand, controlled continuous cattle grazing with light to moderate stocking levels that are stopped early in the summer would likely increase the vegetation quality and balance community composition in favor of forbs and browse, which would be beneficial for wild ungulates.

\section{Acknowledgments}

We would like to thank an anonymous referee for valuable comments.

Authors are MSc Candidate,nchaikin@ucalgary.ca (Chaikina); and Professor (Ruckstubl), Department of Biological Sciences, University of Calgary, Calgary, Alberta, Canada T2N1N4. Research was funded by Discovery Grant 316189-2005 RGPIN from the Natural Sciences and Engineering Research Council of Canada and an Alberta Graduate Scholarship, University of Calgary. Funding was also obtained from Parks and Protected Areas.

\section{Literature Cited}

1. Austin, D. D., P. J. Urness, And L. C. Fierro. 1983. Spring livestock grazing affects crested wheatgrass regrowth and winter use by mule deer. Journal of Range Management 36:589-593.

2. BOWYER, R. T., AND V. C. BLEICH. 1984. Effects of cattle grazing on selected habitats of southern mule deer Odocoileus hemionus fuliginatus. California Fish and Game 70:240-247.

3. DeMArchi, D. A. 1973. Relationship of range quality to range condition in the Chilcotin region, British Columbia. Journal of Range Management 26:345-348.
4. Skovlin, J. M., P. J. Edgerton, and B. R. McConnell. 1983. Elk use of winter range as affected by cattle grazing, fertilizing, and burning in southeastern Washington. Journal of Range Management 36:184-189.

5. Loomis, J., D. Donnelly, And C. Sorg-Swanson. 1989. Comparing the economic value of forage on public lands for wildlife and livestock. Journal of Range Management 42:134-138.

6. Dasmann W. P. 1949. Deer-livestock forage studies on the interstate winter deer range in California. Journal of Range Management 2:206-212.

7. Mishra, C., S. E. Van Wieren, P. Ketner, I. M. A. HeitKonig, And H. H. T. Prins. 2004. Competition between domestic livestock and wild bharal Pseudois nayaur in the Indian Trans-Himalaya. Journal of Applied Ecology 41:344-354.

8. Loft, E. R., J. W. Menke, J. G. Kie, and R. C. Bertram. 1987. Influence of cattle stocking rate on the structural profile of deer hiding cover. Journal of Wildlife Management 51(3):655-664.

9. JenKs, J. A., And D. M. Leslie, JR. 2003. Effect of domestic cattle on the condition of female white-tailed deer in southern pine-bluestem forests, USA. Acta Theriologica 48(1):131-144.

10. Singer, F. J., V. C. M. PAPOUChis, And K. A. Symonds. 2000. Translocation as a tool for restoring populations of bighorn sheep. Restoration Ecology 8(4S):6-13.

11. McMahan, C. A., And C. W. Ramsey. 1965. Response of deer and livestock to controlled grazing in central Texas. Journal of Range Management 18:1-6.

12. Vavra, M., M. J. Willis, And D. P. Sheehy. 1999. Livestock-big game relationships: conflicts and compatibilities In: K. L. Launchbaugh, K. D. Sanders, and J. C. Mosely [eds.]. Grazing behavior of livestock and wildlife. Station Bulletin 70. Moscow, ID: University of Idaho. p 130-136.

13. CAMPBell, E. G., AND R. L. Johnson. 1983. Food habits of mountain goats, mule deer, and cattle on Chopaka Mountain, Washington, 1977-1980. Journal of Range Management 36:488-491.

14. Olsen, F. W., AND R. M. Hansen. 1977. Food relations of wild free-roaming horses to livestock and big game, Red Desert, Wyoming. Journal of Range Management 30:17-20.

15. MACKIE, R. J. 1978. Impacts of livestock on wild ungulates. Transactions of the North American Wildlife and Natural Resources Conference 43:462-476.

16. Hansen, R. M., And L. D. ReID. 1975. Diet overlap of deer, elk, and cattle in southern Colorado. Journal of Range Management 28:43-47.

17. Willms, W., A. McLean, R. Tucker, And R. Ritcey. 1980. Deer and cattle diets on summer range in British Columbia. Journal of Range Management 33:55-59.

18. Kingery, J. L., J. C. Mosley, And K. C. Bordwell. 1996. Dietary overlap among cattle and cervids in northern Idaho forests. Journal of Range Management 49:8-15.

19. Pordomingo, A. J., AND T. Rucci. 2000. Red deer and cattle diet composition in La Pampa, Argentina. Journal of Range Management 53:649-654. 
20. Stewart, K. M., R. T. Bowyer, J. G. Kie, B. L. Dick, And M. BEN-DAVID. 2003. Niche partitioning among mule deer, elk, and cattle: do stable isotopes reflect dietary niche? EcoScience 10:297-302.

21. Hansen, R. M., R. C. Clark, and W. LaWhorn. 1977. Foods of wild horses, deer, and cattle in the Douglas Mountain area, Colorado. Journal of Range Management 30:116-118.

22. Thill, R. E., AND A. Martin, JR. 1989. Deer and cattle diets on heavily grazed pine-bluestem range. Journal of Wildlife Management 53:540-548.

23. Thill, R. E. 1984. Deer and cattle diets on Louisiana pine-hardwood sites. Journal of Wildlife Management 48:788-798.

24. Ortega, I. M., S. Soltero-Gardea, D. L. Drawe, and F. C. BRYANT. 1997. Evaluating grazing strategies for cattle: deer and cattle food partitioning. Journal of Range Management 50:622-630.

25. Bissonette, J. A., And M. J. SteinkamP. 1996. Bighorn sheep response to ephemeral habitat fragmentation. Great Basin Naturalist 56:319-325.

26. KIE, J. G. 1996. The effects of cattle grazing on optimal foraging in mule deer (Odocoileus hemionus). Forest Ecology and Management 88:131-138.

27. Loft, E. R., J. G. KIE, AND J. W. Menke. 1993. Grazing in the Sierra Nevada: home range and space use patterns of mule deer as influenced by cattle. California Fish and Game 79:145-166.

28. Stewart, K. M., R. T. Bowyer, J. G. Kie, N. J. Cimon, And B. K. Johnson. 2002. Temporospatial distributions of elk, mule deer, and cattle: resource partitioning and competitive displacement. Journal of Mammalogy 83:229-244.

29. Thill, R. E., AND A. MARTIN. 1986. Deer and cattle diet overlap on Louisiana pine-bluestem range. Journal of Wildlife Management 50:707-713.

30. Crimella C., C. Carenzi, S. Mattiello, and W. Redaelli. 2002. Effect of dairy cattle husbandry on behavioural patterns of red deer (Cervus elaphus) in the Italian Alps. Applied Animal Behaviour Science 79:299-310.

31. Loft, E. R., J. W. Menke, And J. G. KiE. 1991. Habitat shifts by mule deer: the influence of cattle grazing. Journal of Wildlife Management 55:16-26.

32. Yeo, J. J., J. M. Peek, W. T. Wittinger, and C. T. Kvale. 1993. Influence of rest-rotation cattle grazing on mule deer and elk habitat use in east-central Idaho. Journal of Range Management 46:245-250.

33. Halstead, L. E., L. D. Howery, G. B. Ruyle, P. R. KrausMAN, AND R. J. STEIDL. 2002. Elk and cattle forage use under a specialized grazing system. Journal of Range Management 55:360-366.

34. Skovlin, J. M., P. J. Edgerton, And R. W. Harris. 1968. The influence of cattle management on deer and elk. Transactions of the North American Wildlife and Natural Resources Conference 33:169-181.

35. ClegG, K. 1994. Density and feeding habits of elk and deer in relation to livestock disturbance [MS thesis], Logan, UT: Utah State University. $41 \mathrm{p}$.
36. Coe, P. K., B. K. Johnson, J. W. Kern, S. L. Findholt, J. G. KIE, AND M. J. WisDOM. 2001. Responses of elk and mule deer to cattle in summer. Journal of Range Management 54:A51-A76.

37. Coe, P. K., B. K. Johnson, K. M. Stewart, and J. G. Kie. 2004. Spatial and temporal interactions of elk, mule deer, and cattle. Transactions of the North American Wildife and Natural Resource Conference 69: 656-669.

38. FrisinA, M. R. 1992. Elk habitat use within a rest-rotation grazing system. Rangelands 14:93-96.

39. Knowles, C. J., AND R. B. CAmpbell. 1981. Distribution of elk and cattle in a rest-rotation grazing system. In: J.M. Peek and P.D. Dalke [eds.]. Wildlife-Livestock Relationships Symposium: Proceedings 10. Moscow, ID: University of Idaho, Forestry, Wildlife and Range Experimental Station. p 47-60.

40. Ragotzkie, K. E., AND J. A. Bailey. 1991. Desert mule deer use of grazed and ungrazed habitats. Journal of Range Management 44:487-490.

41. DuseK, G. L. 1975. Range relations of mule deer and cattle in prairie habitat. Journal of Wildlife Management 39:605-616.

42. Austin, D. D., AND P. J. URness. 1986. Effect of cattle grazing on mule deer diet and area selection. Journal of Range Management 39:18-21.

43. Hart, R. H., K. W. Hepworth, M. A. Smith, and J. W. WAGGONER, JR. 1991. Cattle grazing behavior on a foothill elk winter range in southeastern Wyoming. Journal of Range Management 44(3):262-266.

44. Westenskow-Wall, K. J., W. C. Krueger, L. D. Bryant, AND D. R. ThOmas. 1994. Nutrient quality of bluebunch wheatgrass regrowth on elk winter range in relation to defoliation. Journal of Range Management 47:240-244.

45. Wambolt, C. L., M. R. Frisina, K. S. Douglass, and H. W. SHERWOOD. 1997. Grazing effects on nutritional quality of bluebunch wheatgrass for elk. Journal of Range Management 50:503-506.

46. Clements, C. D., And J. A. Young. 1997. A viewpoint: rangeland health and mule deer habitat. Journal of Range Management 50:129-138.

47. JUlAnder, O. 1962. Range management in relation to mule deer habitat and herd productivity in Utah. Journal of Range Management 15:278-281.

48. Wilson, A. D., And N. D. Macleod. 1990. Overgrazing: present or absent. Journal of Range Management 44(5):475-482.

49. VAVRa, M., AND D. P. Sheehy. 1996. Improving elk habitat characteristics with livestock grazing. Rangelands 18:182-185.

50. Garrison, G.A. 1953. Effects of clipping on some range shrubs. Journal of Range Management 6:309-317.

51. SCOTTER, G.W. 1980. Management of wild ungulate habitat in the western United States and Canada: a review. Journal of Range Management 33:16-27.

52. ANDERSON, E. W., AND R. J. SCHENINGER. 1975. Improving quality of winter forage for elk by cattle grazing. Journal of Range Management 28:120-125.

53. GallinA, S. 1993. White-tailed deer and cattle diets at $\mathrm{La}$ Michilia, Durango, Mexico. Journal of Range Management 46:467-492. 
54. Stuth, J. W., AND A. H. WinWard. 1977. Livestock-deer relations in the lodgepole pine-pumice region of central Oregon. Journal of Range Management 30:110-116.

55. Warren, R. J., AND L. J. KRYSL. 1983. White-tailed deer food habits and nutritional status as affected by grazing and deer-harvest management. Journal of Range Management 36:104-109.

56. Gibbens, R. P., And A. M. Schultz. 1962. Manipulation of shrub form and browse production in game range improvement. California Fish and Game 48:49-64.

57. Willms, W., A. Mclean, R. Tucker, And T. Ritchie. 1979. Interactions between mule deer and cattle on big sagebrush range in British Columbia. Journal of Range Management 32:299-304.

58. GoRDON, I. J. 1988. Facilitation of red deer grazing by cattle and its impact on red deer performance. Journal of Applied Ecology 25(1):1-10.

59. Tueller, P. T., AND J. D. Tower. 1979. Vegetation stagnation in three-phase big game exclosures. Journal of Range Management 32:258-263.

60. Brown, E. R., And C. F. Martinsen. 1967. Vegetational changes on some eastern Washington winter game ranges. Paper presented at the 20th annual meeting, American Society of Range Management; 13-17 February 1967; Seattle, WA. 9 p.

61. Hudson, R. J., D. M. Hebert, And V. C. Brink. 1976. Occupational patterns of wildlife on a major east Kootenay winter-spring range. Journal of Range Management 29:38-43.
62. Bastian, C. T., J. J. Jacobs, L. J. Held, and M. A. Smith. 1991. Multiple use of public rangeland: antelope and stocker cattle in Wyoming. Journal of Range Management 44:390-395.

63. Smith, A. D., AND D. D. Doell. 1968. Guides to allocating forage between cattle and big game on big game winter ranges. Salt Lake City, UT: Utah State Division of Fish and Game Publications 68-1. 32 p.

64. Loomis, J. B., E. R. Loft, D. R Updike, AND J. G. Kie. 1991. Cattle-deer interactions in the Sierra Nevada: a bioeconomic approach. Journal of Range Management 44:395-399.

65. Cohen, W. E., D. L. Drawe, F. C. Bryant, and L. C. BRADLEY. 1989. Observations on white-tailed deer and habitat response to livestock grazing in south Texas. Journal of Range Management 42:361-365.

66. Martinez, M. A., V. Molina, F. S. Gonzalez, J. S. MarroQUIN, AND J. NAVAR. 1997. Observations of white-tailed deer and cattle diets in Mexico. Journal of Range Management 50:253-257.

67. Damiran, D., T. DelCurto, S. L. Findholt, G. D. PulSIPHER, AND B. K. JOHNSON. 2003. Influence of previous cattle and elk grazing on the subsequent quality and quantity of diets for cattle, deer and elk grazing late-summer mixed-conifer rangelands. Proceedings of the Western Section, American Society of Animal Science 54:320-324. 